\title{
The Roots of Ecological Crisis in the Philippines in the Lens of Martin Heidegger's Philosophy of Technology
}

\author{
Melchor Labao Cuizon \\ Department of Social Sciences, Central Luzon State University, Science City of Munoz, Nueva Ecija, Philippines \\ Email address: \\ cuizonmel@clsu.edu.ph \\ To cite this article: \\ Melchor Labao Cuizon. The Roots of Ecological Crisis in the Philippines in the Lens of Martin Heidegger's Philosophy of Technology. \\ International Journal of Philosophy. Vol. 9, No. 3, 2021, pp. 143-147. doi: 10.11648/j.ijp.20210903.14
}

Received: July 17, 2021; Accepted: July 26, 2021; Published: August 2, 2021

\begin{abstract}
The Philippines is one of the countries that are susceptible to natural calamities every year it is experiencing countless numbers of typhoons which resulted in the loss of lives and massive destruction of properties. This phenomenon can be attributed to the increasing destruction and deterioration of the environment caused by excessive and misguided principles. Accordingly, these principles are motivated by the uncontrolled numbers of the human population, economic sustainability, and even political agenda. Although these factors are significant in understanding the cause of the ecological crisis, nevertheless it does not capture the roots of the problem. This paper aims to provide a deeper analysis on the issue using Martin Heidegger's framework particularly his analysis on the nature of revealing that dominated modern technology. The "enframing" attitude of modern technology, as well as the parasitic response of humanity to the revealing of the natural world, is the root cause of the ecological crisis. Although humanity is destined by the enframing attitude brought about by modern technology, nevertheless, it does not make him a slave. A true relationship with the natural world that is free from the im - posing character of enframing is possible through "sober thinking". A kind of thinking or realization that took place after the intoxicating effects of the technocratic paradigm that enables us to return to the natural revealing of nature and thrives for a possible revealing that enhances both the human person and the physis.
\end{abstract}

Keywords: Martin Heidegger, Ecological Crisis, Questions Concerning Technology, Technology

\section{Introduction}

The Philippines is one of the countries in the world that is susceptible to typhoons being situated in a "Pacific Ring of Fire". The report of the Asian Disaster Reduction Center, there are approximately at least twenty tropical cyclones enter the country yearly and some of them are potentially destructive [1]. An article written by Brown in Time magazine describes the Philippines as "the most exposed country in the world to tropical storms" [2]. Just this year 2020, the country experiences a disastrous effect of succeeding typhoons that hit particularly in the National Capital Region. The effects of the typhoons are catastrophic hence it triggers uncontrolled floods and landslides affecting a vast area of lands particularly in the province of Isabela and the municipality of Marikina.

The typhoons that regularly strike the country are a natural phenomenon that is unpredictable and beyond human control. The devastating effects of the typhoons are paralleled to the present crisis of the environment which is mainly anthropogenic in origin where the environment is jeopardized because of the uncontrolled and unregulated consumption of its natural resources.

One contributing factor that affects this ecological crisis is the increasing numbers of the population throughout the world. In the tragedy of the commons, Hardin categorically links the destruction of the "commons" to the ever-growing number of people directly affecting the world's space and natural resources. Other factors such as economic and social problems are just the result of the population issue [3].

Although the above factors are significant in understanding the cause of the ecological crisis, nevertheless it does not capture the roots of the problem. It is the task of this paper to provide a philosophical basis for understanding the issue from the lens of Martin Heidegger's philosophy of technology. This paper shall argue that the root cause of ecological crisis primarily in the Philippines is grounded in a "parasitic" response to modern technology. The discussion 
highlights his reflection on technology as a mode of revealing that is respectful to nature. This is followed by situating Heidegger's ideas of "enframing" as the root cause of the ecological crisis in the country. The concluding part shall reiterate Heidegger's reflection on "gaining a free relationship with technology" as a way of liberating humanity's manipulative and exploitative disposition to the natural world.

\section{Technology as a Mode of Revealing}

The discourse of technology begins in the work of Martin Heidegger entitled Die Frage Nach der Technik."His analysis is geared towards the understanding of technology in both the ancient and the modern periods. What follows is my discussion on Heidegger's reflection on the primordial revealing free from manipulation and exploitation of the natural environment.

Technology as proposed by Heidegger cannot be captured by mere definition. The prevailing understanding of technology is embedded in the discourse of causality which is an issue for Heidegger. Technology understood as the interplay of cause and effect is reductionist and does not capture its very essence. Thus, understood in this way technology will remain a threat and "danger as such" for this way of framing the natural environment is one-dimensional, which is purely subjective.

To avoid this tragedy, Heidegger reminisces the revealing of nature which predominates the early Greeks' mind. His argument on "ancient technology" is captured by his use of several terms such as "being indebted," "being responsible," "hypokeisthai", "starting something on its way," "occasioning," "inducing", "poiesis", "bringing-forth" "physis", "revealing," and "aletheuein [4]".

Heidegger illustrates this idea in several examples such as the "silver chalice", the "traditional farming", the "windmill" and the "River Rhine". Here, technology is at work but respectfully enhances both the object and the subject. In traditional farming, for instance, both the field and the crops are not forcefully demanded to produce a maximum harvest at the minimum expense, rather both the field, the crops, the peasant, and the forces of nature work in complete harmony to bring forth the harvest according to the potential latent in the crops. This is also true with the Rhine River before it was transformed into a hydroelectric dam [5]. Here, technology is never perceived as mere means nor in the prevalent notion of causality as cause and effect rather, technology is thought of as an end in which the four causes and the material conditions are all indebted to each other to bring - forth the concealed into unconcealment [6]. This is the essence of technology that Heidegger is proposing, a revealing grounded on the reciprocal relationship of physis and phoiesis.

This poiesis and physis character of revealing as argued by Heidegger is still evident in the Philippines. The rice terraces of Ifugao and the underground water of Palawan manifest this primordial revealing of nature. Their inclusion as world heritage by the United Nations Educational, Scientific and
Cultural Organization (UNESCO) is a remarkable manifestation of the intermingling activity of poiesis and physis, a testimony of how this cultural landscape gently develops without resulting in im - position and exploitation of nature. This is an evident example of the role of the human person not as an efficient cause but as a "shepherd of beings". In bringing - forth something into presencing the human person serves as the midwife and nurturer which cooperates with the material conditions and the forces of nature in the overall activity for accomplishing its determined purpose.

This Heidegger's reflection on primordial technology charged him with being an ontological conservative. The reply is negative. The issue can be responded to by intuitively understand Heidegger's reflection on the essence of technology that predominates the modern age. At the advent of reason, human subjectivity rules superior to the external world from which the entities of the world are reduced to an optional necessity. When the environment or nature is put to mere "option" the substantive meaning is lost and the object or entity becomes an inventory of options which according to Heidegger unfold nature to give its resources unreasonably as demanded by the human person itself. The reduction of nature into objectlessness and standing - reserve put it on the brink of destruction. In a word, Heidegger's critique on the revealing of the modern age is grounded on the im - posing attitude of the human person towards the environment [7].

\section{Modern Technology as the Root Cause of the Ecological Crisis}

The revealing that predominates the modern period is contrary to the natural revealing of nature which is "bringing - forth" in the sense of poiesis [5]. The kind of revealing that prevails in the modern period is a challenging - forth which treated nature as "stockpiled of resources" that can be "extracted and stored as such" [4]". This way of revealing advances the energies and resources of nature into a manifold of transformation, unlocking, and indeterminate distribution [5]. In the observation of De Vera the problem is rooted in the human person's exposure to a lot of technai which eventually transforms his natural disposition of the natural world into an im - posing disposition that dichotomizes his humanity from nature [8]. This "enframing" character of the modern age places the human person to set up the natural world which is distinct from him thus, "blocking the shining forth and holding sway of truth" of the natural world [5].

This "enframing" attitude of the time endangered the vast areas of land and mountains of the Philippines. An advertisement of the Financial Times of 1989 as cited by Carino in a Cultural Survival Quarterly Magazine, describes the Philippines as "more densely mineralized than Australia, where the tonnages are larger and the terrain is largely unexplored. The country is estimated to be second only to South Africa in its average gold reserves per square kilometer." This attracted a lot of companies around the 
world "as the most favorable to mining" and where the Philippines acted a mining law since 1995. This is one among the many human activities which resulted in ecological disparity and the diminishing forest situation of the country [9]. Added to this ecological disruption is the transformation of mountainous areas into an agricultural field, residential houses, industry, and the Build, Build, Build infrastructure projects of the present administration which displaces the indigenous community and brink to destruction the vast areas of land and forests in the country [10].

An article published by Hance situates the rampant illegal logging and mining as the primary cause of the massive destruction of lives and property in the Compostela Valley during the typhoon Pablo. This perennial problem of the country is due to the lack of law enforcement, the evergrowing problem of corruption by bribing people engaged in illegal activities [11]. By patronizing products that use woods as raw materials such as papers and furniture which according to Baustita is historical in origin going back to American colonialism from 1920. The extraction of forests is economically grounded on the principle of sustainability to cater to the demand for log production. Early in the 1970s, this unceasing exploitation of the Philippine forests transformed the physical landscape into a stockpiled of resources ready to be unlocked, exposed, and distributed [12].

It can be said that the flooding of almost the whole province of Cagayan, Isabela this November 2020, is the after-effects of illegal logging and deforestation which extracted 20,000-35,000 cu. m wood annually [13]. This can also be attributed to the perennial problem of Marikina City, although the main issue is the overflowing of water from the Marikina River due to the excessive rain, hence the city is considered as the catch basin from the mountain top areas. But for whatever reason, the problem of flooding in the city is the result of illegal activities such as the removal of forests and the conversion of the natural landscape into residential houses and agricultural farms.

The same case that can be attributed to a costly disaster in Mindanao especially in Cagayan de Oro during a tropical storm Sendong in December 2011 in which deforestation and the massive illegal logging was identified as the main contributor of the loss of lives and properties in the city. Other factors such as massive urbanization and the restructuring of the city subjected a large number of forest and land areas into residential houses, the agricultural field, and tourism accreditation [14].

The most destructive and costly disaster that shivers not only the Philippines but the entire world is the typhoon Yolanda or Haiyan in November of 2013 which kills around 10,000 inhabitants in Tacloban, Leyte [15]. Although the catastrophe is attributed primarily to climate change due to excessive emissions of greenhouse gasses by developed countries in the world nevertheless, it cannot be doubted that deforestation and illegal logging in the area is evident which contributes to the worsening effects of climate change [16].

Heidegger lament that humanity has successfully poison and mechanistically transform the natural environment into a "stockpile of resources" and granted him the position to "reveal the real, in the mode of ordering, as standing reserve" [5]. This enframing attitude of the modern age according to Heidegger driven the human person to reduce reality on its technological or instrumental value where nature according to Khong is ordered according to its availability, profitability, and marketability [17]. In this manner of revealing, nature and even the human person itself undermines its creative engagement and thus, creates a gap between the object and the subject, where nature as the object lacks its intrinsic value. The gap brought about by this mode of revealing does not only alienates us but eventually leads to massive destruction of the natural environment [18].

This im - posing character gestured by modern technology threatens the environment by reducing it into measurable and calculable objects and conceals the truth and the meaningful and unique encounter of the human person and the environment. Dreyfus added that this im - position does not only affect the environment but the human person as well. Here, the person is reduced to standing - reserve and in return, this can make us believe that we are the master and lords of creation. What is restricted in enframing is that it conceals us in the overall understanding of being, for it only reveals the technological aspect of reality which Heidegger describes as expediting for we are both sucked into standing - reserves and the object of exploitation [19]. This mode of revealing brought about by modern technology gestures the present ecological crisis. As argued by Collingwood changes in the conception of nature begin when the modern perception of cosmology and environment is motivated by the advances of science and technology geared towards innovation and development. This progressive development transforms the ancient notion of nature into a more complicated relationship that upholds a purely anthropocentric understanding [20].

Furthermore, this mode of revealing that prevails modern technology is likened to a duel. In a duel, the persons involved are the challenger and the ones being challenged. Here both the challenger and the challenged person are given the chance to defend their own life making the act honorable and praiseworthy. The challenging-forth brought about by the revealing of modern technology, in contrast, is inhumane and not praiseworthy precisely because nature is defenseless yet demanded to satisfy the insatiable cravings of the human person [4]. As Heidegger argues, it is the demand on nature beyond what it can give an assumption that such nature stored limitless supply of minerals and resources which can be taken out wantonly and without reservation.

This technological mode of revealing which Heidegger argues changes the human person's relation to nature. It creates destruction by luring the person into inauthenticity for it hides the truth by merely perceiving nature as raw materials for humanity's exploitation and consumption. In addition, this mode of revealing brought by modern technology conceals the possibility of nature to reveal the truth; instead, it reveals only its technological aspect [21]. This technological aspect of technology as argued by 
Heidegger tends to unlock, transform, store, and distribute the resources that nature has to offer [5]. In a word, modern technologies incline to treat nature as a standing reserve [Bestand].

As a standing - reserve the primary motivation is to reduce nature as calculable objects as well as reducing the human person as the orderer of the standing reserve. This is a delusion for Rojcewicz [4] and De Luca, a belief that the human person takes the place of God as an orderer, lord, and master on the earth [22]. Thus, the existence of nature or the environment is dependent on man as a mental construct.

The danger of this mode of revealing challenges forth the energies and resources of nature into a kind of advances that further drives the human person to gain unlimited resources at the minimum expense. This insatiable desire of the human person to exploit nature at the maximum yield as expound has driven the person to uncontrolled use of technology. The enframing brought by technology distanced him/her from nature and at the same time allowing him/her to be controlled by the same technology. This challenging revealing, setting upon, ordering, standing reserve of the contemporary technology is oppressive and exploitative which constitutes environmental crisis and crimes against nature [23]. By destroying nature and having believed that we are the lords of the earth and that the world functions just to meet our needs and demands we lose sight of the truth (Alethia) and the essence of being a human person.

For Dreyfus \& Spinosa this destruction of nature is not only the result of the human person's technological advancement but rather it leads to the distortion of his/her very self. This technological lifestyle prompted by the revealing of modern technology curtail our capacity to be open to the further revealing of nature. In a statement Heidegger caution that this technicity at present when tolerated will eventually lead the human person to greater perdition. This endless transformability of the resources of nature primarily eliminates its intrinsic potential for further discoveries [24].

This change of the original revealing according to Heidegger is not a human contribution or failure rather this change of revealing from the Aristotelian causality to the causality of imposition that dominated modern technology is the consequence of the withdrawal of Beings. Accordingly, as Heidegger argues, the concealment of Being causes the human person a distorted sense which makes it possible to perceive everything in nature as only matter imbued with unlimited potentials in the service of humanity. This imperious attitude brought about by the revealing of modern technology is the result of the eclipse of the disclosive looking upon Being. As a consequence, the human person becomes possessive and submissive to the unbridled imposition of ends Rojcewicz [4] which Tabachnick further describes as inhospitable and inhumane since technology is revealed beyond human control produces things beyond our hopes [25].

On the question, if Heidegger is a fatalist, again the reply is negative. Although humanity is destined to this enframing attitude of the modern age, nevertheless, it does not confine him to be "denied to experience the primordial revealing". Heidegger quoted Holderlin's verse on the possibility of salvation brought about by the danger of enframing. He said, "where danger is, grows the saving power also" [5]. The possibility of saving humanity from the entrapment of modern technology will be the focus of the concluding part of this reflection.

\section{Conclusion}

According to Heidegger, although humanity is destined to be technological, nevertheless, it is not our fate. Heidegger argues that the key to overcoming our technicity resulted from the enframing of the modern period is through "sober thinking". This kind of thinking aspires the human person towards the proper disposition on the revealing of nature and be able to articulate the difference of technology in the mode of poiesis and technology conceived according to its instrumental and anthropological value. This kind of thinking which Heidegger suggested is free from delusion and intoxication of technological advancement. Wrathall describes this "soberness" as thinking or realization that took place after the intoxicating effects of the technological paradigm which still leaves the human person empty and meaningless [7]. This realization says Tabachnick is grounded on the realization that after being annihilated by the overwhelming technology of the modern age, we come to realized our failures, anxiety, and terror which enable us to return to the natural revealing of nature and thrives for a possible revealing that enhances both the human person and the physis [25].

This kind of thinking is embodied by the Japanese people where Dreyfus beautifully illustrates the Japanese disposition towards primordial technology alongside modern technology. This is evident in the Japanese teacup ceremony which still exists even in the modern age. What is remarkable in these cultural practices are the Japanese understanding on the openness of being, for instead of replacing a styrofoam cup, they retained their delicate teacup that is preserved and handed down for future generation. Despite the advancement of the Japanese people on modern technology, the tea ceremony is a living example that even human persons are destined to be the orderer of the standing reserve of the natural world it is not our fate to be sucked on the problematic and disastrous effects of the destining of enframing [19].

\section{Recommendations}

A related study on the topic can be done using Pope Francis's encyclical entitled "Laudato $\mathrm{Si}^{\prime \prime}$ on how this document explores the root cause of the ecological crisis which resulted in climate change and other environmental issues. Another related issue on the topic that can also be explored is environmental literacy during this time of the COVID-19 pandemic. An evaluation or assessment of 
whether or not a significant relationship exists between knowledge, belief, and practices on the disposals of COVID paraphernalia.

\section{References}

[1] Asian Disaster Reduction Center (ADRC). Information on Disaster Risk Reduction of the Member Countries. https://www.adrc.asia/nationinformation.php?NationCode $=60$ $8 \&$ Lang $=$ en

[2] Brown, S. (2013, November 11). The Philippines is the most storm-exposed country on earth. Time. http://world.time.com/2013/11/11/the-philippines-is-the-moststorm-exposed-country-on-earth/ CaoDai.org.

[3] Hardin, G. (1968). The Tragedy of the Commons. Science, New Series, Vol. 162, No. 3859, pp. 1243-1248. http://www.jstor.org/stable/1724745.

[4] Rojcewicz. Richard. (2006). The Gods and Technology: A Reading of Heidegger. Albany: State University of New York Press.

[5] Heidegger, M. (1977). The question concerning technology and other essays, translated with an introduction by William Lovitt, 115-154. New York and London: Garland Publishing.

[6] Carino, Jovito V. (2009). Heidegger and the Danger of Modern Technology. Philippiniana Sacra. Vol. XLIV, No. 132. pp. 491-504.

[7] Wrathall, Mark A. (2019). The Task of Thinking in a Technological Age. Heidegger on Technology. Aaron James Wendland, Christopher Merwin, and Christos Hadjioannou (edit.). Routledge, Taylor and Francis, New York).

[8] De Vera, D. A. (2013). Towards a return to one's essence: Some reflections on Nietzsche and Heidegger. Journal of Philosophy of Life, Vol. 3, No. 2: 108-126.

[9] Carino, J. (2001, September). The Environmental Crisis in the Philippines. Cultural Survival Quarterly Magazine. https://www.culturalsurvival.org/publications/culturalsurvivalquarterly/environmental-crisis-Philippines

[10] IBON Foundation. (2000, April 27). A glimpse at the critical state of the Philippine Environment. https://www.ibon.org/aglimpse-at-the-critical-state-of-the-philippine-environment/

[11] Hance, J. (2012, December 06). Illegal logging, mining worsened the impact of the Philippines' killer typhoon. Mongabay. http://news.mongabay.com/2012/1206-hancetyphoon.

[12] Bautista, G. (1990). The forestry crisis in the Philippines: Nature, causes, and issues. The developing economies 28 (1), 67-94.
[13] Ploega, JV., Weerd, MV, Masipiquenac, AB., and GA. Persoon. (2011). "Illegal Logging in the Northern Sierra Madre Natural Park, The Philippines." Conservation and Society 9 (3): 202-215.

[14] Frantal, B., Quiaoit, H. A. R., Lo, D., \& Narisma, G. (2016, November). Climate Disasters in the Philippines: A Case Study of Immediate Causes and Root Drivers from Cagayan de Oro, Mindanao, and Tropical Storm Sendong/Washi. Environment \& Natural Resources Program. Belfer Center for Science and International Affairs Harvard Kennedy School. www.belfercenter.org/ENRP Philippine-environment/

[15] IBON (2015). Disaster upon disaster: Lessons beyond Yolanda. Quezon City.

[16] Holden, W. N. (2018). Typhoons, climate change, and climate injustice in the Philippines. Austrian Journal of South-East Asian Studies, 11 (1), 117-139.

[17] Khong, L. (2003). Actants and enframing: Heidegger and Latour on technology. Studies in History and Philosophy of Science, 34 693-704. https//doi: 10.1016/j.shpsa.2003.09.003

[18] Crowell, S. (2019). The challenge of Heidegger's approach to technology. In A. J. Wendland., C. Merwin., \& C. Hadjioannou (Ed.), A phenomenological reading in Heidegger on technology. Taylor and Francis Routledge.

[19] Dreyfus, H. (2002). Heidegger on Gaining a Free Relation to Technology. Heidegger Reexamined: Arts, Poetry, and Technology. Hubert Dreyfus \& Mark Wrathall (ed.). Routledge, Taylor, and Francis. New York City.

[20] Collingwood, R. (1945). The idea of nature. Oxford university press.

[21] Lack, Anthony. Martin Heidegger on Technology, Ecology, and the Arts. (New York: Palgrave Macmillan Publishers, 2014).

[22] De Luca, K. M. (2005). Thinking with Heidegger: Rethinking environmental theory and practice. Ethics and the environment, Vol. 10, (1), 67 - 87. DOI: 10.1353/een.2005.0013.

[23] White, Rob: Crimes against Nature. Environmental criminology and ecological justice. Willan Publishing. Culmcott House, 2008).

[24] Dreyfus, H., \& Spinosa, C. (2003). Further reflections on Heidegger, technology, and the everyday. Bulletin of Science Technology \& Society 23: 339. SAGE. DOI: $10.1177 / 0270467603259868$.

[25] Tabachnick, D. E. (2006). "The Tragic Double Bind of Heidegger's Techné”. In PhaenEx 1, N. 2, (fall/winter 2006), 94-112. 